\title{
Prevalence of chronic arthritis in four geographical areas of the Scottish Highlands
}

\author{
M M Steven
}

\begin{abstract}
A survey of the prevalence of chronic arthritic conditions was carried out on a population of 35251 patients registered with 29 general practitioners in the highlands of Scotland. Symptomatic osteoarthritis had an overall prevalence of 65 per 1000 but rose from one in 20 of those aged 40-50 years to one quarter of those over 70 years of age. Rheumatoid arthritis was present in 5.5 per 1000 with a two to threefold female preponderance and there was an unexplained threefold difference between the regions with the highest and lowest prevalence. Seronegative arthritides were found in $2 \cdot 1$ per 1000 , polymyalgia rheumatica/temporal arteritis in 1.2 per 1000 , and gout in 3.4 per 1000 . Juvenile chronic arthritis had a prevalence of 0.39 per $1000(2.0$ per 1000 in those aged 15 years and younger) and connective tissue disease 0.45 per 1000 .

There was considerable variation in the prevalence of inflammatory arthritis throughout the region. The highest prevalence of rheumatoid arthritis was 14.5 per 1000 women in one east coast area and the lowest 5.2 per 1000 women in the west. The difference did not seem to be due to misclassification.

A consultant's review of a questionnaire sent to all except those with osteoarthritis changed the proportions of patients who could be confirmed to have the respective inflammatory arthritides (rheumatoid arthritis between 3.4 and 5.0 per 1000 , seronegative arthritides 2.0 per 1000 , juvenile chronic arthritis 0.52 per 1000 ), and a third of those diagnosed as having rheumatoid arthritis failed to meet hospital oriented diagnostic criteria.
\end{abstract}

Rheumatic diseases impose a considerable burden on the health of the community. Whether measured by temporary or permanent inability to work or by general practitioner or hospital consultation rates, they are among the leading causes of morbidity in the United Kingdom. Epidemiological studies on the prevalence of rheumatic diseases have been complicated by the lack of 'hard' diagnostic criteria which are universally agreed and applicable in the community. These and other reasons probably explain the disparate assessments of the prevalence of chronic arthritis.

Useful estimates may depend on the purpose for which a group needs to be identified. Therefore, studies of disease causation or natural history should look at all possible cases of disease, including subclinical or mild forms
On the other hand, studies of health care provision may more reasonably consider only cases of symptomatic disease.

The Highland Arthritis Prevalence Study (HARPS) was designed to assess the prevalence of chronic rheumatic disease in a large geographical area with a single regional rheumatological service which uniquely encompasses east and west coasts of Great Britain.

\section{Patients and methods}

The Highland Health Board provides health care for the Highland region (population 200800 ) with additional specialist provision to the Western Isles (population 31 500) and some cross boundary flow from the West Grampian region (population 84800 ). The population served is comparable with that of an average United Kingdom health district but is scattered over a vast geographical area (9804 square miles) larger than Wales (fig 1 ).

The Highland Health Board has a single consultant with an interest in rheumatology based in Inverness and inpatient facilities for rheumatology are provided by the 15 bedded Nicolson MacKenzie hospital in the spa village of Strathpeffer. Outpatients are seen in Inverness and at peripheral clinics. The region is therefore well defined geographically and served by a single major hospital providing an ideal environment for epidemiological study.

The Highland region is served by 162 general practitioners, including 36 single handed practitioners. Thirty general practitioners from nine general practices initially agreed to take part in the study. They were chosen as representatives of urban and rural practices respectively on the east and west coasts of the area (fig 1). Because

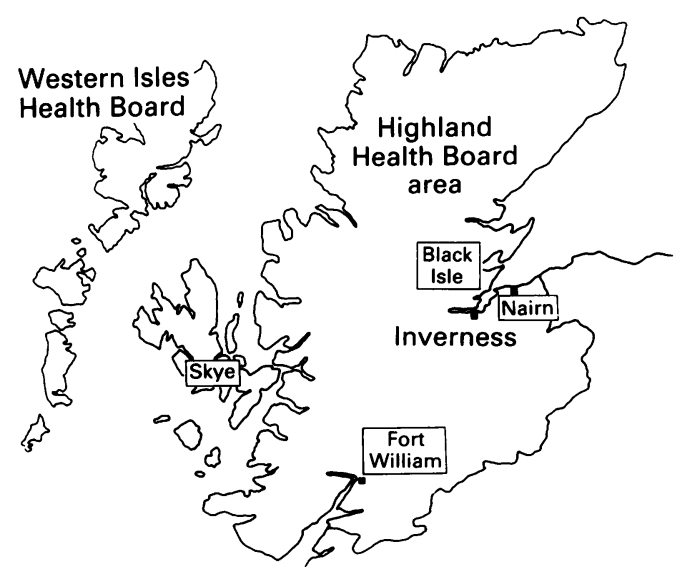

Figure 1 Areas where the prevalence of chronic arthritis was assessed. 
Table 1 Profile of practices in the HARPS* study

\begin{tabular}{|c|c|c|c|c|c|}
\hline \multirow[t]{2}{*}{ Area } & \multirow{2}{*}{$\begin{array}{l}\text { No of GPs } \\
\text { (principles) }\end{array}$} & \multicolumn{3}{|c|}{ No of patients } & \multirow[t]{2}{*}{ Patients/GP } \\
\hline & & Male & Female & Total & \\
\hline $\begin{array}{l}\text { Nairn } \\
\quad \text { Practice } 1 \\
\text { All practices }\end{array}$ & $\begin{array}{l}6 \\
6\end{array}$ & $\begin{array}{l}4521 \\
4521\end{array}$ & $\begin{array}{l}4581 \\
4581\end{array}$ & $\begin{array}{l}9102 \\
9102\end{array}$ & $\begin{array}{l}1517 \\
1517\end{array}$ \\
\hline $\begin{array}{l}\text { Black Isle } \\
\text { Practice 1 } \\
\text { Practice 2 } \\
\text { Practice 3 } \\
\text { All practices }\end{array}$ & $\begin{array}{l}2 \\
2 \\
1 \\
5\end{array}$ & $\begin{array}{r}825 \\
1910 \\
485 \\
3220\end{array}$ & $\begin{array}{r}801 \\
1975 \\
469 \\
3245\end{array}$ & $\begin{array}{r}1626 \\
3885 \\
954 \\
6465\end{array}$ & $\begin{array}{r}813 \\
1942 \\
954 \\
1293\end{array}$ \\
\hline $\begin{array}{l}\text { Lochaber } \\
\text { Practice } 1 \\
\text { Practice } 2 \\
\text { Practice } 3 \\
\text { All practices }\end{array}$ & $\begin{array}{r}4 \\
5 \\
3 \\
12\end{array}$ & $\begin{array}{ll}2 & 157 \\
2 & 424 \\
1 & 984 \\
6 & 565\end{array}$ & $\begin{array}{l}2200 \\
2563 \\
1969 \\
6732\end{array}$ & $\begin{array}{r}4357 \\
4987 \\
3953 \\
13297\end{array}$ & $\begin{array}{r}1089 \\
997 \\
1318 \\
1 \quad 108\end{array}$ \\
\hline $\begin{array}{l}\text { Skye } \\
\quad \text { Practice } 1 \\
\text { Practice } 2 \\
\text { All practices }\end{array}$ & $\begin{array}{l}4 \\
2 \\
6\end{array}$ & $\begin{array}{l}2365 \\
771 \\
3136\end{array}$ & $\begin{array}{r}2426 \\
825 \\
3251\end{array}$ & $\begin{array}{l}4791 \\
1596 \\
6387\end{array}$ & $\begin{array}{r}1198 \\
798 \\
1065\end{array}$ \\
\hline Total HARPS & 29 & 17442 & 17809 & 35251 & 1216 \\
\hline
\end{tabular}

${ }^{*}$ HARPS $=$ Highland Arthritis Prevalence Study.

of the geographical layout of the area, the practices each served virtually all the patients in those areas with little possibility of selective cross boundary flow to neighbouring practices.

There is also no significant private medical practice. One part time practitioner (list size $506)$ in a large group practice later withdrew. Between December 1986 and December 1987 the 29 practitioners from nine practices in the region (table 1) prospectively collected details of all patients on their personal NHS list known to have chronic arthritis. In all, 35251 patients were reviewed. Practitioners were asked to identify all patients who had chronic arthritis of more than six months' duration in order to estimate the point prevalence of these conditions in the Highland region. Individual practitioners reviewed their diagnostic indices, repeat prescribing registers, practice records, and an up to date print out of the names and addresses of all patients registered with the practice (provided by the primary care division, Highland Health Board). In this way all patients with chronic arthritis registered with the practice were identified, not only those who consulted during the study period. The initial details collected, including the names, addresses, sex, date of birth, and specific diagnosis, were entered on a tailored relational database (Dataflex) and stored on a microcomputer (Victor 20 MB personal computer). The specific diagnosis used was that made by the general practitioner from their knowledge of the patient, their own records, and hospital letters, where available (table 2). It was emphasised that of the patients with osteoarthritis, only those who were symptomatic were to be included.

Owing to the widely scattered population and the large number of patients it was not possible to carry out a diagnostic validation including a specialist consultation. A computer generated questionnaire was therefore sent out to the practitioner according to the diagnosis requesting detailed clinical information. Owing to the large number of patients with osteoarthritis (about 80 for each practitioner) it was not possible to collect information on this group. The questionnaire sought details of clinical features, serology, and radiology (appendix), enabling a consultant rheumatologist to review the general practitioner diagnosis. Records of those attending the regional rheumatology outpatient or inpatient departments during the study period were also inspected to check the level of ascertainment by

Table 2 The chronic* arthritides

\begin{tabular}{|c|c|}
\hline \multicolumn{2}{|l|}{ Symptomatic osteoarthritis } \\
\hline \multicolumn{2}{|c|}{$\begin{array}{l}\text { Rheumatoid arthritis } \\
\text { (seropositive and seronegative rheumatoid factor) }\end{array}$} \\
\hline $\begin{array}{l}\text { Ankylosing spondylitis } \\
\text { Psoriatic arthritis } \\
\text { Arthritis of inflammatory bowel disease } \\
\text { Reiter's disease } \\
\text { Other seronegative arthritis }\end{array}$ & $\begin{array}{l}\text { Seronegative } \\
\text { arthritides }\end{array}$ \\
\hline \multicolumn{2}{|l|}{ Juvenile chronic arthritis } \\
\hline \multicolumn{2}{|l|}{ Polymyalgia rheumatica/temporal arthritis } \\
\hline \multicolumn{2}{|l|}{ Gout } \\
\hline $\begin{array}{l}\text { Systemic lupus erythematosus } \\
\text { Scleroderma } \\
\text { Polymyositis/dermatomyositis } \\
\text { Polyarteritis nodosa/other vasculitides }\end{array}$ & $\begin{array}{l}\text { Connective tissue } \\
\text { disease }\end{array}$ \\
\hline
\end{tabular}

${ }^{*}$ Present for six months or longer. 
Table 3 Number of diagnoses of chronic arthritis

\begin{tabular}{|c|c|c|c|c|c|c|c|c|c|c|}
\hline \multirow[t]{2}{*}{ Area } & & \multirow{2}{*}{$\begin{array}{l}\text { Practice } \\
\text { size }\end{array}$} & \multicolumn{8}{|c|}{ Type of chronic arthritis } \\
\hline & & & $O A^{*} \ddagger$ & $R A^{*}$ & $S N^{*}$ & $\mathscr{F C A}$ & $P M R / T A$ & Gout & $C T D^{*}$ & $A R^{*}$ \\
\hline Nairn & & 9102 & 461 & 41 & 14 & 1 & 7 & 10 & 3 & 0 \\
\hline Black Isle & $\begin{array}{l}1 \\
2 \\
3\end{array}$ & $\begin{array}{r}1626 \\
3885 \\
954\end{array}$ & $\begin{array}{r}134 \\
241 \\
81\end{array}$ & $\begin{array}{r}6 \\
50 \\
4\end{array}$ & $\begin{array}{l}2 \\
5 \\
3\end{array}$ & $\begin{array}{l}1 \\
1 \\
0\end{array}$ & $\begin{array}{r}3 \\
12 \\
1\end{array}$ & $\begin{array}{r}3 \\
32 \\
4\end{array}$ & $\begin{array}{l}1 \\
4 \\
0\end{array}$ & $\begin{array}{l}4 \\
1 \\
1\end{array}$ \\
\hline Lochaber & $\begin{array}{l}1 \\
2 \\
3\end{array}$ & $\begin{array}{l}4357 \\
4987 \\
3953\end{array}$ & $\begin{array}{r}718 \\
92 \\
126\end{array}$ & $\begin{array}{l}22 \\
21 \\
30\end{array}$ & $\begin{array}{r}9 \\
13 \\
9\end{array}$ & $\begin{array}{l}3 \\
3 \\
2\end{array}$ & $\begin{array}{r}11 \\
0 \\
3\end{array}$ & $\begin{array}{r}29 \\
9 \\
4\end{array}$ & $\begin{array}{l}4 \\
3 \\
1\end{array}$ & $\begin{array}{r}0 \\
13 \\
3\end{array}$ \\
\hline Skye & $\begin{array}{l}1 \\
2\end{array}$ & $\begin{array}{l}4791 \\
1596\end{array}$ & $\begin{array}{r}370 \\
60\end{array}$ & $\begin{array}{r}14 \\
7\end{array}$ & $\begin{array}{r}12 \\
2\end{array}$ & $\begin{array}{l}2 \\
1\end{array}$ & $\begin{array}{l}6 \\
0\end{array}$ & $\begin{array}{r}26 \\
3\end{array}$ & $\begin{array}{l}0 \\
0\end{array}$ & $\begin{array}{l}5 \\
3\end{array}$ \\
\hline Total HARPS $†$ & & 35251 & 2283 & 195 & 69 & 14 & 43 & 120 & 16 & 30 \\
\hline
\end{tabular}

*OA=symptomatic rheumatica osteoarthritis; $\mathrm{RA}=$ rheumatoid arthritis; $\mathrm{SN}=$ seronegative arthritis; JCA=juvenile chronic arthritis; $\mathrm{PMR} / \mathrm{TA}=$ polymyalgia rheumatica temporal arteritis; $\mathrm{CTD}=$ connective tissue disease; $\mathrm{AR}=$ other arthritis. tHARPS $=$ Highland Arthritis Prevalence Study.

fOne hundred and twelve patients had osteoarthritis and another arthritis: $\mathrm{RA}=51 ; \mathrm{SN}=3 ; \mathrm{PMR}=20 ; \mathrm{GT}=37$; CT $=1$.

the general practitioner. Data were analysed to measure the overall and regional point prevalence of chronic arthritis in the Highland region.

\section{Results}

During the 12 month study period 2770 diagnoses of chronic arthritis were made by the general practitioners. These included 112 patients with more than one diagnosis (table 3 ). Fourteen patients died during the study period and were excluded from further consideration. More than three quarters of the cases identified were patients with symptomatic osteoarthritis, which had an overall prevalence of 65 per 1000 population. There was considerable variation with age, varying from one in 20 of the population aged $40-50$ years up to one quarter of those over 70 years (fig 2). There was a slight female excess but little regional variation.

Based on the general practitioner's own diagnosis rheumatoid arthritis was the most prevalent inflammatory arthritis with an overal prevalence of 5.5 per 1000 (6.9 per 1000 for those aged more than 15 years). There was a two to threefold female preponderance (table 4) and the prevalence rose from under 10 per 1000 women at age 40-50 years to a peak of 23 per 1000 women aged $60-70$ (fig 3). There was a threefold difference in prevalence between the Black Isle (9.3 per 1000) and Skye (3.3 per 1000).

Seronegative arthritides, including ankylosing spondylitis, psoriatic arthritis, and Reiter's disease, had an overall prevalence of $2 \cdot 1$ per 1000 , less than half that of rheumatoid arthritis. There was a reversal of the female predominance seen in rheumatoid arthritis, and in some areas

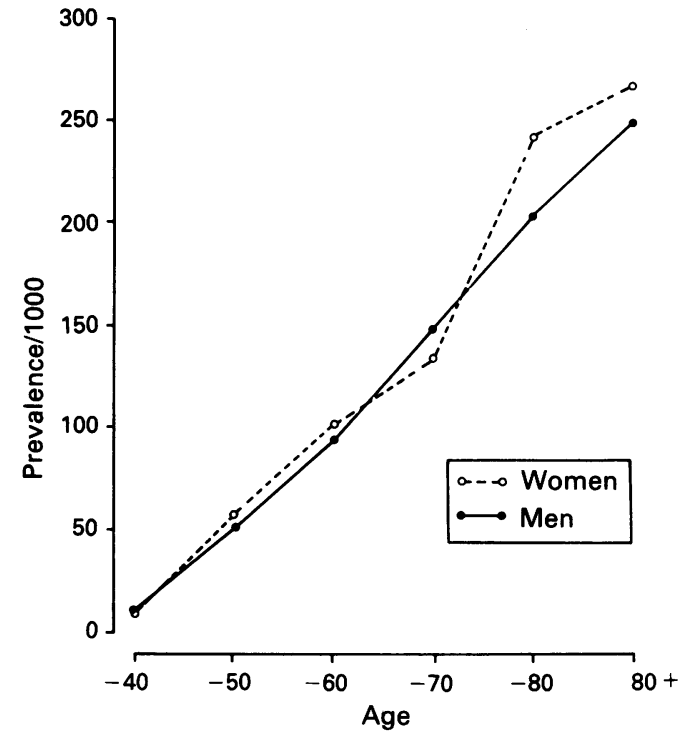

Figure 2 Prevalence of osteoarthritis by age and sex in a population of 35251 general practice patients.

the male prevalence of seronegative arthritis exceeded that of rheumatoid arthritis.

Other inflammatory arthritides were less common. Juvenile chronic arthritis had a prevalence of 0.39 per $1000(2.0$ per 1000 for those aged 15 years and younger) and polymyalgia rheumatica was reported in 1.2 per 1000 population. There were more women than men with both juvenile chronic arthritis $(0.6$ per 1000 women $v 0.2$ per 1000 men) and polymyalgia rheumatica/temporal arteritis (table 4). Connective tissue disease was rare (overall prevalence 0.45 per 1000 ), and the numbers were too small (16) to make any comparisons between areas.

Table 4 Prevalence of arthritis per 1000 population by general practitioner diagnosis

\begin{tabular}{|c|c|c|c|c|c|c|c|c|c|c|}
\hline \multirow[t]{2}{*}{ Area } & \multicolumn{2}{|l|}{$R A^{*}$} & \multicolumn{2}{|l|}{$S N^{*}$} & \multicolumn{2}{|l|}{ Gout } & \multicolumn{2}{|c|}{$P M R / T A^{*}$} & \multicolumn{2}{|l|}{$O A$} \\
\hline & Men & Women & Men & Women & Men & Women & Men & Women & Men & Women \\
\hline $\begin{array}{l}\text { Nairn } \\
\text { Black Isle } \\
\text { Lochaber } \\
\text { Skye } \\
\text { Total HARPS: }\end{array}$ & $\begin{array}{l}2 \cdot 7 \\
4 \cdot 0 \\
3 \cdot 7 \\
1 \cdot 7 \\
3 \cdot 0\end{array}$ & $\begin{array}{r}6 \cdot 3 \\
14 \cdot 5 \\
7 \cdot 3 \\
5 \cdot 2 \\
8 \cdot 0\end{array}$ & $\begin{array}{l}1 \cdot 3 \\
1 \cdot 9 \\
3 \cdot 2 \\
2 \cdot 5 \\
2 \cdot 4\end{array}$ & $\begin{array}{l}1.7 \\
1.8 \\
1.5 \\
1.8 \\
1.7\end{array}$ & $\begin{array}{l}1 \cdot 8 \\
8 \cdot 7 \\
5 \cdot 3 \\
7 \cdot 3 \\
5 \cdot 3\end{array}$ & $\begin{array}{l}0 \cdot 4 \\
3 \cdot 1 \\
1.5 \\
1.5 \\
1.5\end{array}$ & $\begin{array}{l}0 \cdot 4 \\
0 \cdot 9 \\
0 \cdot 8 \\
0 \cdot 3 \\
0 \cdot 6\end{array}$ & $\begin{array}{l}1 \cdot 1 \\
4 \cdot 0 \\
1 \cdot 3 \\
1 \cdot 5 \\
1 \cdot 8\end{array}$ & $\begin{array}{l}50 \cdot 8 \\
61 \cdot 5 \\
59 \cdot 7 \\
53 \cdot 6 \\
56.6\end{array}$ & $\begin{array}{l}50 \cdot 4 \\
79 \cdot 5 \\
80 \cdot 8 \\
80 \cdot 6 \\
72 \cdot 7\end{array}$ \\
\hline
\end{tabular}

${ }^{*}$ For abbreviations see table 3 . 


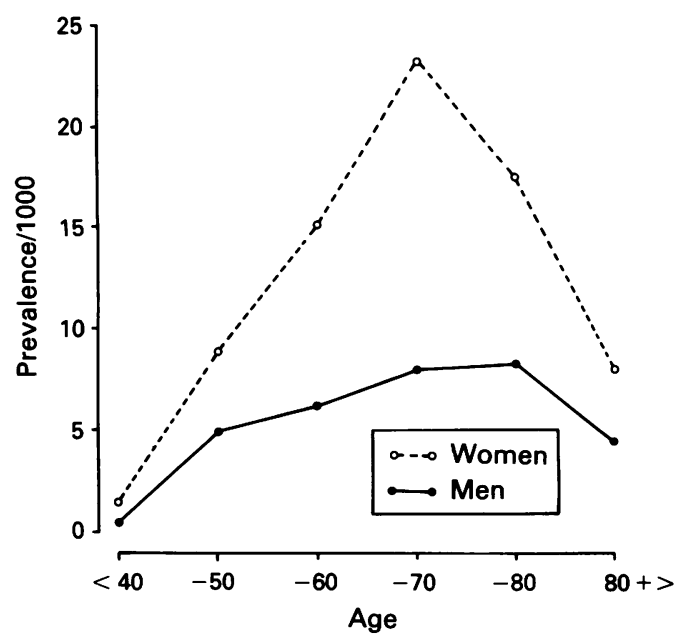

Figure 3 Prevalence of rheumatoid arthritis by age and sex in a population of 35251 general practice patients.

Thirty patients were diagnosed as 'other arthritis', including spondylolisthesis, neuropathic joints, haemophilic arthritis, and primary bone diseases.

The diagnostic rate for gout varied widely throughout the region (table 4 ) with a regional prevalence of 3.4 per 1000 and a substantial excess of men.

In an attempt to validate the general practitioner's diagnosis further details were obtained by a questionnaire sent to all patients other than those with osteoarthritis. Twenty six practitioners returned all their questionnaires, but three were unable to complete theirs giving an overall completion rate of $88 \%$. Not all patients had undergone full serological and radiological assessment. Tables 5 and 6 give details of the returned questionnaires. Of the 170 patients with a general practitioner diagnosis of rheumatoid arthritis, six had a concurrent diagnosis of psoriasis. Although four had a symmetrical, radiologically erosive polyarthritis affecting small joints and another was seropositive for rheumatoid factor, these six patients were all considered to have psoriatic arthritis. In one other case classed as rheumatoid arthritis by the practitioner the onset of arthritis had been in childhood and should be considered as a case of juvenile chronic arthritis. Of the remainder, 84 had rheumatoid arthritis which was considered 'moderate' or 'severe' (appendix). Sixty six of those had either erosive hand radiographs or were seropositive for rheumatoid factor, or both. Six had had neither test performed and the remaining 12 had non-diagnostic results. On the basis of the clinical features, however, all 18 were considered to have confirmed rheumatoid arthritis (figure 4).

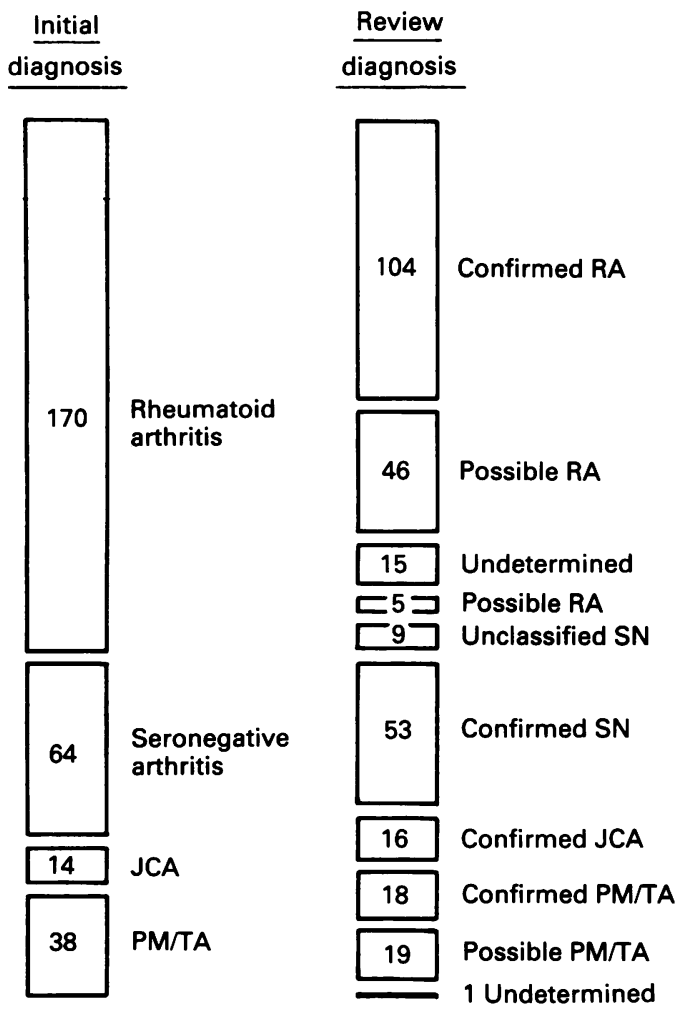

Figure 4 Review of general practitioner diagnosis by analysis of returned questionnaires. $R A=$ rheumatoid arthritis; $S N=$ seronegative arthritis; $\mathcal{F C A}=$ juvenile chronic arthritis; $P M=$ polymyalgia $; A=$ temporal arteritis.

Table 5 Diagnostic features of patients with general practitioner diagnosis of rheumatoid arthritis and seronegative arthritis

\begin{tabular}{|c|c|c|c|c|c|c|c|c|}
\hline \multirow[t]{2}{*}{ Diagnostic feature } & \multicolumn{3}{|c|}{ Rheumatoid arthritis $(n=170)$} & \multicolumn{5}{|c|}{ Seronegative arthritis $(n=64)$} \\
\hline & $\begin{array}{l}\text { Moderate or } \\
\text { severe } \\
(n=89)\end{array}$ & $\begin{array}{l}\text { Earlv } \\
(n=39)\end{array}$ & $\begin{array}{l}\text { Atvpical } \\
(n=42)\end{array}$ & $\begin{array}{l}\text { Psoriatic } \\
\text { arthritis } \\
(n=23)\end{array}$ & $\begin{array}{l}\text { Unclassified } \\
\text { seronegative } \\
\text { arthritis } \\
(n=16)\end{array}$ & $\begin{array}{l}\text { Ankylosing } \\
\text { spondylitis } \\
(n=13)\end{array}$ & $\begin{array}{l}\text { Inflammatory } \\
\text { bowel disease } \\
(n=5)\end{array}$ & $\begin{array}{l}\text { Reactive } \\
\text { arthritis } \\
(n=7)\end{array}$ \\
\hline Men:women & $18: 71$ & $10: 29$ & $15: 27$ & $12: 11$ & $7: 9$ & $11: 2$ & $3: 2$ & $5: 2$ \\
\hline Age:range (median) & $32-90(62)$ & $34-101(59)$ & $24-71(52)$ & $30-64(50)$ & $31-77(52)$ & $22-63(48)$ & $24-60(40)$ & $27-67(43)$ \\
\hline $\begin{array}{l}\text { Disease duration: } \\
\text { range (median) }\end{array}$ & $2-38(12)$ & $1-30(4)$ & $1-30(3)$ & $0-24(6)$ & $1-14(7)$ & $1-37(9)$ & $1-24(3)$ & $4-20(6)$ \\
\hline $\begin{array}{l}\text { Rheumatoid factor } \\
\text { Positive* } \\
\text { Negative } \\
\text { Unknown }\end{array}$ & $\begin{array}{l}57 \\
18 \\
14\end{array}$ & $\begin{array}{r}24 \\
12 \\
3\end{array}$ & $\begin{array}{r}26 \\
14 \\
2\end{array}$ & $\begin{array}{r}0 \\
17 \\
6\end{array}$ & $\begin{array}{r}2 \\
13 \\
1\end{array}$ & $\begin{array}{l}2 \\
4 \\
7\end{array}$ & $\begin{array}{l}0 \\
2 \\
3\end{array}$ & $\begin{array}{l}0 \\
6 \\
1\end{array}$ \\
\hline $\begin{array}{l}\text { Radiograph of hands } \\
\text { Erosive } \\
\text { Normal } \\
\text { Other } \\
\text { Unknown }\end{array}$ & $\begin{array}{r}52 \\
3 \\
9 \\
25\end{array}$ & $\begin{array}{r}10 \\
6 \\
7 \\
16\end{array}$ & $\begin{array}{r}4 \\
12 \\
5 \\
21\end{array}$ & $\begin{array}{l}5 \\
5 \\
5 \\
8\end{array}$ & $\begin{array}{l}1 \\
4 \\
4 \\
7\end{array}$ & $\begin{array}{r}0 \\
1 \\
0 \\
12\end{array}$ & $\begin{array}{l}0 \\
1 \\
2 \\
2\end{array}$ & $\begin{array}{l}2 \\
3 \\
0 \\
2\end{array}$ \\
\hline $\begin{array}{l}\text { Radiograph of pelvis } \\
\text { Sacroiliitis } \\
\text { Normal } \\
\text { Unknown }\end{array}$ & 二 & - & - & $\begin{array}{r}6 \\
2 \\
15\end{array}$ & $\begin{array}{l}1 \\
6 \\
9\end{array}$ & $\begin{array}{l}8 \\
3 \\
2\end{array}$ & $\begin{array}{l}1 \\
0 \\
4\end{array}$ & $\begin{array}{l}2 \\
3 \\
2\end{array}$ \\
\hline
\end{tabular}

"Rheumatoid factor greater than 60 IU 
Table 6 Diagnostic features of patients with general practitioner diagnosis of juvenile chronic arthritis $(\mathcal{F C A})$, gout, polymyalgia rheumatica $(P M R)$, or connective tissue disease (CTD)

\begin{tabular}{lllll}
\hline & $f C A(n=14)$ & Gout $(n=111)$ & $P M A(n=38)$ & $C T D(n=15)$ \\
\hline $\begin{array}{l}\text { Men:women } \\
\text { Age:range (median) }\end{array}$ & $5: 9$ & $86: 25$ & $10: 28$ & $4: 11$ \\
$\begin{array}{l}\text { Disease duration: } \\
\text { range (median) }\end{array}$ & $3-61(12)$ & $30-91(59)$ & $57-92(78)$ & $32-77(59)$ \\
$\begin{array}{l}\text { Rheumatoid factor } \\
\text { Positive }\end{array}$ & $1-50(4)$ & $0-23(5)$ & $0-13(3)$ & $1-22(5)$ \\
$\begin{array}{l}\text { Negative } \\
\text { Unknown }\end{array}$ & 2 & - & - & 5 \\
$\begin{array}{l}\text { Radiograph of hands } \\
\quad \text { Erosive }\end{array}$ & 5 & - & - & 6 \\
$\quad \begin{array}{l}\text { Normal } \\
\text { Other }\end{array}$ & 5 & - & - & 2 \\
$\quad$ Unknown & 6 & - & - & 2 \\
\hline
\end{tabular}

${ }^{*}$ Rheumatoid factor greater than $60 \mathrm{IU}$

Of 38 patients considered to have early rheumatoid arthritis, serological tests or radiology, or both, led to a diagnosis of confirmed rheumatoid arthritis in 18 patients. One patient had no objective joint swelling and had normal hand radiographs and was seronegative for rheumatoid factor and was classed as undetermined diagnosis. The remaining 19 had nondiagnostic results, but the clinical features suggested a diagnosis of possible rheumatoid arthritis.

The remainder, comprising 41 patients, were considered to have atypical rheumatoid arthritis. In 14 the clinical features were considered undetermined for a diagnosis of rheumatoid arthritis or any other chronic inflammatory arthritis. Twenty seven had one or more features that were suggestive but not diagnostic, and they were classed as 'possible' rheumatoid arthritis.

Sixty four patients who returned questionnaires had a diagnosis of seronegative arthritis (table 5). These included patients with coexistent psoriasis or inflammatory bowel disease as well as those with ankylosing spondylitis and reactive arthritis/Reiter's disease. The pattern of joint disease and other features reflects the different clinical subgroups of these diseases. One patient with seronegative arthritis was found to have had a childhood onset and was accordingly reclassified. Fifty three patients were considered to have a confirmed diagnosis after consultant review. There remained a group of patients with seronegative arthritis which did not readily fit any of the other diagnostic subgroups. Although not part of any classification, they are a well represented group at most specialist clinics.

Two of this group had symmetrical peripheral joint disease and were seropositive for rheumatoid factor and were therefore reclassified as confirmed rheumatoid arthritis. Five others had similar clinical features and were seronegative but could be considered to have possible rheumatoid arthritis. The remaining nine had largely asymmetrical disease or large joints with or without spinal involvement and could represent formes frustes of ankylosing spondylitis or other seronegative disease.

A review of questionnaires from patients with gout showed the expected male pre- dominance (table 6). Over $90 \%$ of those tested had hyperuricaemia. Diagnostic crystal analysis was not used by general practitioners for diagnosis, but the diagnosis could not be rebutted in any case.

Patients with polymyalgia rheumatica/ temporal arteritis were older (median age 78 years) and had a 2:8:1 female predominance. Thirty four had a dramatic or good response to steroid treatment but only 18 of 32 tested had an erythrocyte sedimentation rate greater than 60 $\mathrm{mm} / \mathrm{h}$ (or equivalent plasma viscosity) at diagnosis. One patient had had neither a significantly raised erythrocyte sedimentation rate/ viscosity nor a good or dramatic response to steroid treatment and could not be confirmed as a definite case.

Patients diagnosed as having connective tissue disease included eight with systemic lupus erythematosus, two with dermatomyositis, and five with unclassified forms. Three had concurrent rheumatoid arthritis and were considered to have overlap syndromes. All patients with this diagnosis had attended hospital and the diagnoses were therefore considered valid.

Patients with juvenile chronic arthritis (table 6) were supplemented by two classified in adult groups by their practitioner (both seronegative for rheumatoid factor). Five had a Still's type of disease, four were considered to have oligoarticular arthritis, and four polyarticular disease. Three others did not fit any of these diagnostic patterns.

After reclassification (fig 4) there were, therefore, 62 patients with seronegative arthritis and 16 with juvenile chronic arthritis. There were 104 confirmed, 51 possible, and 15 undetermined cases of rheumatoid arthritis. There were 18 confirmed cases of polymyalgia rheumatica and 19 further possible cases. When these figures were related to the overall population from whom questionnaires were returned (30 899) we obtained a prevalence of seronegative arthritis of $2 \cdot 0$ per 1000 and of rheumatoid arthritis between 3.4 (confirmed) and 5.0 (confirmed plus possible) per 1000 depending on the criteria accepted as diagnostic. The prevalence of juvenile chronic arthritis increased slightly to 0.52 per 1000 total population.

A review of patients who had attended a 
specialist rheumatology clinic during the study period was carried out. No cases were identified from the hospital records of patients who had been missed by the general practitioner study.

\section{Discussion}

Epidemiological studies of the arthritides are beset by many problems. Some are common to all medical epidemiology and some particular to rheumatic diseases. Choosing cases identified by the patient's own (different) doctor may result in variable rates of pickup. The rates of self presentation to practitioners vary between individual patients as do the diagnostic rates and disease classification between doctors. In the absence of specific diagnostic markers for rheumatic diseases there is considerable scope for intra- and interobserver variation, even among experts. Alternative epidemiological techniques, such as community screening programmes, are not immune from these difficulties and additionally encounter the problem of asymptomatic subjects with clinical or laboratory signs of the disease under study. ${ }^{2}$ This study, therefore, chose the level of general practitioner identification as the most practicable and meaningful for assessing the prevalence of chronic arthritis and the demands on health resources.

Numerically, osteoarthritis of the elderly is the major problem, the prevalence of symptomatic osteoarthritis rising from $10 \%$ in those aged $50-60$ to nearly $25 \%$ of those over 80 . The study of the Royal College of General Practitioners found an episode rate of 29.0 per 1000 for osteoarthritis in a large general practice based study but only included those who attended their doctor complaining of their joint symptoms during the study. ${ }^{3}$

An American study estimated the prevalence of clinical osteoarthritis at $12 \cdot 1 \%$ of the adult population. ${ }^{4}$ Community based screening programmes in several countries have shown radiological signs of osteoarthritis to be virtually universal in the elderly, ${ }^{45}$ but these figures are of little value in assessing the impact of symptomatic disease on health resources. At present the management of this condition includes drugs, physiotherapy, and orthopaedic surgery, including joint replacement. Demand for surgery is growing steadily, partly because of its efficacy and partly because of the increasing elderly (and hence osteoarthritic) population. Provision of facilities currently follows and hence lags behind demand, which has resulted in long waiting lists for joint replacement surgery. There are no good estimates of the optimal provision of this facility to aid health planners.

Inflammatory arthritis as exemplified by rheumatoid arthritis and seronegative arthritis is much less common than osteoarthritis. Because these two diseases begin in middle life and because they are often chronic they also place large demands on health and other social resources. Our current estimate of the overall prevalence of rheumatoid arthritis in the Highland region lies between 0.34 and $0.55 \%$ of the population.
Previous studies in Western societies have shown variable prevalences dependent on the criteria for diagnosis and the population studied. ${ }^{1}$ Strict diagnostic criteria which identify chronic disease produce lower prevalences than widely used criteria which identify many cases of apparently self limiting inflammatory arthritis. A consensus for the prevalence of rheumatoid arthritis in the developed world would be $1 \%$ of the adult population. ${ }^{124}$ Our current figure is lower than this but cannot be compared directly with most studies owing to differences in the methodology. A more comparable study, such as the morbidity statistics from general practice, recorded an episode rate of 5.9 per 1000 population for rheumatoid arthritis and allied conditions. ${ }^{3}$ Although comparable with our own figure, this study did not distinguish other inflammatory arthritides and only included patients who attended for a consultation about their arthritis during the study period. The study was carried out in volunteer practices in England and Wales, which might not have been representative. Nevertheless, this study supports our own estimate of rheumatoid arthritis as being considerably less than that previously cited, and it may be that the prevalence of rheumatoid arthritis is actually falling.

We also noticed the commonly found two- to threefold excess of women over men, though it is less apparent in younger and older groups. The fall in prevalence over the age of 70 is well recognised ${ }^{67}$ and thought to represent an excess mortality in rheumatoid arthritis.

A subregional analysis shows an excess of rheumatoid arthritis in the Black Isle, especially in women. This remains even when all inflammatory arthritides are considered together or when osteoarthritis is added (table 4). Misclassification would not therefore explain the excess. Rheumatoid arthritis is considered to have a significant genetic component and it may be relevant that Huntington's disease, which has a much stronger inherited component, has a high prevalence on the Black Isle.

Seronegative disorders were less common than rheumatoid arthritis, and there are no community based studies with which to compare our results. The study from the Royal College of General Practitioners did not distinguish this group from those with rheumatoid arthritis. ${ }^{3}$ In contrast with rheumatoid arthritis men are more commonly affected by seronegative arthritis. The review of general practitioner diagnoses by a consultant rheumatologist suggested some cases of seronegative arthritis had been misclassified as rheumatoid arthritis. These disorders were relatively more common in Lochaber and Skye and again may reflect a familial predisposition.

Connective tissue diseases are rare in the United Kingdom and our low prevalence figure reflects this. Juvenile chronic arthritis is also uncommon but as it can produce considerable morbidity at a young age there is considerable implication for the provision of health care to this group. Our figures suggest 520 cases per million of the population and might suggest the advisability of providing regional or supra- 
regional treatment centres for this difficult clinical problem. A recent review estimated 12000 cases of juvenile chronic arthritis in the United Kingdom, ${ }^{8}$ which gives an approximate prevalence of 214 per million, which is less than our regional assessment.

Although perhaps $5 \%$ of the population may have hyperuricaemia, chronic symptomatic gout is less common and affected less than $0.5 \%$ of the local population. The prevalence elsewhere is not well established, though the condition is common in some populations, such as the New Zealand Maoris. A questionnaire study in the United States produced a self reported prevalence of gout of $0.99 \%,{ }^{4}$ but community studies requiring a medical assessment failed to confirm two thirds of self reported cases. ${ }^{9}$

Many scientific studies of chronic arthritis have considered only patients attending hospital and it has been suggested that they form an unrepresentative group. We found that in this area nearly three quarters of all patients with inflammatory arthritis had attended hospital (data not shown), but they tended to be those with more severe or chronic conditions and patients with self limiting or early arthritis may not be represented. It is thus important to acknowledge the unrepresentative nature of patients who attend hospital. Community based studies remain constrained by the lack of hard diagnostic criteria as this and previous studies ${ }^{2} 4$ have shown. Diagnostic subclassification based on hospital experience may be unhelpful in community studies and there is a case for considering inflammatory arthritis as a single diagnosis in this setting.

Epidemiological studies can provide clues which may implicate environmental or genetic factors in disease and direct studies aimed at identifying them. There are particular difficulties in collecting groups of patients with chronic inflammatory arthritis that are representative yet homogeneous in the absence of suitable objective diagnostic markers. This study has detected a large community based cohort of patients with chronic arthritis and has highlighted subregional differences in their prevalence. Such a population can be used to audit the level of health care provided for subjects and to search for genetic and environmental factors which may be relevant to the pathogenesis of arthritis.

I acknowledge the cooperation of my general practitioner colleagues and the assistance of their practice staff. Mr R A Bowie of Prosoft Systems Analysis wrote and supported the computer software. Professor J H Barber and Dr F Sullivan of computer software. Professor $\mathrm{J} H$ Barber and Dr F Sullivan of the department of general practice, University of Glasgow, and Dr H I McNamara, regional adviser in general practice, Raigmore Hospital gave valuable advice and encouragement at the outset of the study. Mrs E Robb coordinated the data collection and analysis and typed the manuscript.

The project was supported by a grant from the health services research committee of the Scottish Home and Health Department.

1 Hochberg M C. Adult and juvenile rheumatoid arthritis: current epidemiological concepts. Epidemiol Rev 1981; 3: $27-44$

2 Wood P H N, Badley E M. Epidemiology of individual rheumatic diseases. In: Scott I T, ed. Copeman's textbook of rheumatic diseases. 6th ed. Edinburgh: Churchill Livingrheumatic diseases. 6th

3 Royal College of General Practitioners. Morbidity statistics from general practice 1981-82. London: HMSO, 1986.
4 Lawrence R C, Hochberg M C, Kelsey J L, et al. Estimates of the prevalence of selected arthritic and musculoskeletal diseases in the United States. F Rheumatol 1989; 16 $427-41$.

5 Gordon T. Osteoarthrosis in U.S. adults. In: Bennet P H Wood $\mathrm{P}$ H N, eds. Population studies of the rheumatic diseases. Amsterdam: Excerpta Medica, 1968: 391-7.

6 Vanderbroucke J P, Hazevoet H M, Cats A. Survival and causes of death in rheumatoid arthritis: a prospective follow-up. I Rheumatol 1984; 11: 158-61.

7 Spector T D, Scott D L. What happens to patients with cheumatoid arthritis? The long term outcome of treatment. Clin Rheumatol 1988; 7: 315-30.

8 Benjamin C M. Review of the UK data on the rheumatic diseases. 1-Juvenile chronic arthritis. Br $\mathcal{F}$ Rheumatol 1990; diseases. 1-J $231-3$.

9 O'Sullivan J. Gout in a New England town, prevalence study in Sudbury Massachusetts. Ann Rheum Dis 1972; 31: 166-9.

APPENDIX Questionnaire sent to general practitioners

The following questionnaire was sent to general practitioners on patients other than those with osteoarthritis. A prototype questionnaire for rheumatoid arthritis is shown and questions 4-7 were modified for other diagnoses.

VICTOR GENERATED HARPS QUESTIONNAIRE

Patient's usual doctor to complete and return.

Please use the practice record, including any hospital letters, and your knowledge of the patient to complete the form.

If you don't know the answer to any question, please state so.

Patient's name

Address

Date of birth

Sex

HARPS No

1 Diagnosis

Rheumatoid arthritis (RA)

2 Year of diagnosis

3 Year of assessment

4 Pattern of involvement

(Circle correct response)

Early classical

Symmetrical inflammation without deformity of wrist and finger joints $+/$ - one or two large joints

Moderate classical Symmetrical inflammation with early deformities of wrist and finger joints $+/-$ one or more larger joints

Severe classical

Severe symmetrical deformity of wrist and finger joints and larger joints with or without inflammation

Atypical

Other patterns

N.B. Large joints include shoulders, elbows, hips, knees, and ankles

5 Are there or have there been objective signs of join swelling?

YES/NO

6 Are there or have there been extra-articular mani- 
festations of RA? (Include nodules, vasculitis, scleritis, pulmonary, and other organ involvement.)

YES/NO

7 Is or was morning stiffness a prominent symptom? YES/NO

8 Is there a history of arthritis (other than osteoarthritis) or any other related diseases in a relative? YES/NO

9 What was the highest recorded rheumatoid factor in GP notes, including hospital letters?

(Give Rose-Waaler dilution or nephelometry units. If not done, state not done.)

10 What was the highest recorded ESR/plasma viscosity in GP notes, including hospital letters?

(If not done, state not done.)

11 Are there hand/foot x-ray reports?

YES/NO If YES, are they
(a) Normal
(b) Non-specific change
(c) Degenerative changes (OA)
(d) Erosive changes (RA)?

12 Has the patient had

(a) Outpatient hospital assessment of arthritis?

(b) Inpatient hospital treatment for arthritis? YES/NO (If YES, please state hospital number

13 Does the patient suffer from any of the following? (Tick any that apply).

Ischaemic heart disease Peptic ulcer disease

Hypertension

Asthma

Other bowel/liver disease

Stroke

Cancer

naemia - (Non vitamin B-12)

deficient)

Chronic renal disease Thyroid disease

Psoriasis Diabetes

Neurological disease Eye disease

Significant depression

14 Does the patient suffer from any other form of arthritis? If YES, please state what

YES/NO

\section{MODIFICATIONS}

1 Diagnosis Seronegative arthritis

Ankylosing spondylitis/psoriatic arthritis/arthritis with inflammatory bowel disease

(Please circle appropriate diagnosis)

(a) If psoriatic arthritis, state duration of psoriasis

(b) If inflammatory bowel disease, state duration of disease and whether ulcerative colitis or Crohn's ..........................

2 Does it affect

(a) Cervical spin

(b) Lumbar spine

YES/NO

(c) Large periphe

YES/NO YES/NO

(d) Small peripheral joints (carpus, tarsus, fingers, toes)

YES/NO

3 Has there been conjunctivitis or iritis? YES/NO

4 Is there a family history of seronegative disorders including Reiter's disease/reactive arthritis? YES/NO If YES, please state who and what

5 Have the sacroiliac (SI) joints/pelvis been radiographed?

If YES, (a) normal SI joint

YES/NO

(b) Possible sacroiliitis

(c) Definite sacroiliitis

(d) Other
1 Diagnosis Reiter's disease/reactive arthritis (Please circle appropriate diagnosis)

2 Pattern of disease

(a) Single attack

(b) Recurrent attacks

(c) Chronic arthritis

(d) Other (please state)

3 Does it affect

(a) Cervical spine YES/NO

(b) Lumbar spine YES/NO

(c) Large peripheral joints YES/NO

(d) Small peripheral joints (carpus, tarsus, fingers, toes)

YES/NO

If YES for peripheral joints, is there symmetrical involvement?

YES/NO

4 Has there been, or is there conjunctivitis or iritis? YES/NO

5 Has there been, or is there urethritis? YES/NO

6 Has there been, or is there enteritis? YES/NO

7 Is there a past history of other seronegative disorders? YES/NO

If YES, please state which

8 Is there a family history of Reiter's disease or any other seronegative disorders? YES/NO If YES, please state who and what

1 Diagnosis Juvenile chronic arthritis

2 Pattern of disease

(a) Still's (systemic illness $+/-$ arthritis)

(b) Symmetrical (rheumatoid-like) polyarthritis

(c) Asymmetrical polyarthritis

(d) Other (please state)

3 Has there been or is there eye involvement? YES/NO

4 What was the highest recorded antinuclear antibody (ANA)/antinuclear factor in GP notes, including hospital letters?

(Give highest dilution e.g. 1/1064 etc.

If not done, state not done) 
1 Diagnosis Connective tissue disease If known, state SLE/polyarteritis nodosa/scleroderma/polymositis/other

2 Clinical features
(a) Skin changes/vasculitis
Typical/atypical/NO
(b) Raynaud's disease
(c) Arthritis Deforming/non-deforming/NO
(d) Muscle involvement Symptoms/objective
signs/NO
(e) Alopecia
(f) Eye involvement
(g) Neurological
(h) Cardiac
(i) Respiratory
(j) Haematological
(k) Renal
(l) Other-state what
YES/NO
YES/NO
YES/NO
YES/NO
YES/NO
YES/NO

3 What was the highest recorded ANA in the GP notes (including hospital letters)?

Give dilution, state IgG or IgM and pattern of staining if available

4 What is the highest recorded DNA binding (units)?

4 What is the highest recorded DNA binding (units)?

1 Diagnosis Gout, pseudogout (Please circle correct reply)

2 Are symptoms intermittent or chronic? I/C

3 Are there tophi?

YES/NO

4 What is the highest recorded blood urate?

C
(State units/not done) 